\title{
Protein composition of urinary casts from healthy subjects and patients with glomerulonephritis
}

\author{
J K FAIRLEY, J E OWEN， D F BIRCH
}

\begin{abstract}
Urinary casts from 46 healthy volunteers and 60 patients with glomerulonephritis were examined for the presence of Tamm-Horsfall glycoprotein and other proteins. All samples gave immunofluorescence evidence of TammHorsfall protein in casts. Casts from 59 of the patients but only three of the controls contained other proteins in addition $(p<0.001)$. Immunoglobulins (IgG, IgM, IgA) were detected in casts from 53 of the patients but none of the healthy volunteers.

Examination of urinary casts for immunoglobulins, complement, and fibrin provides a non-invasive method for distinguishing patients with active glomerular disease.
\end{abstract}

\section{Introduction}

Despite the common finding of hyaline casts in urine their composition has attracted little attention. Addis believed that they were composed of protein and chondroitin sulphate. ${ }^{1}$ McQueen, however, using a fluorescence antibody technique, showed that their major component was Tamm-Horsfall glycoprotein. ${ }^{2}$ Rutecki et al found a difference between granular casts and hyaline casts: using an immunofluorescence method to search for a wide variety of serum proteins of different molecular size they identified all serum proteins, except $C$ reactive protein, in granules of casts from five patients with glomerulonephritis and three with other renal diseases. ${ }^{3}$

We undertook the present study to determine whether the protein composition of urinary casts from patients with glomerulonephritis was different from that of casts from healthy subjects.

\section{Subjects and methods}

Midstream urine samples were obtained from 60 patients with glomerulonephritis confirmed by biopsy, six patients with diabetes, and six patients with presumed essential hypertension, for which they were receiving a diuretic at the time of the study. Samples were also obtained from 46 healthy volunteers after they had taken strenuous exercise. All samples contained at least 3000 casts $/ \mathrm{ml}$. Samples from patients were examined without knowledge of the clinical or histological findings.

Urine $(30 \mathrm{ml})$ was centrifuged at $1500 \mathrm{~g}$ for seven and a half minutes at $15^{\circ} \mathrm{C}$. The deposit was washed twice with phosphate buffered saline ( $\mathrm{pH} \mathrm{7.3).} \mathrm{Standard} \mathrm{volumes} \mathrm{of} \mathrm{antisera} \mathrm{to} \mathrm{a} \mathrm{range} \mathrm{of} \mathrm{proteins}$ were then added to the washed sediment (table I). The antisera were allowed to act for 20 minutes at room temperature, after which the deposits were washed as before in buffered saline and examined with a Leitz Dialux ultraviolet microscope.

To minimise non-specific fluorescence antisera were titrated before use with positive urine sediments. The degree of fluorescence was graded on a scale of four as bright fluorescence of casts or granules

\footnotetext{
Department of Nephrology, Royal Melbourne Hospital, Parkville 3050, Victoria, Australia

J K FAIRLEY, BSC, graduate assistant

J E OWEN, BSC, graduate assistant

D F BIRCH, PHD, senior research fellow

Correspondence to: Dr D F Birch.
}

within casts; uniform pale fluorescence of casts; weak fluorescence comparable with background structures; or no fluorescence. For the purposes of this study only casts with the greatest degree of fluorescence were classed as positive.

TABLE I-Rabbit antihuman (RAH), sheep antirabbit $(S A R)$, and sheep antihuman $(S A H)$ antisera used for identifying proteins in casts

\begin{tabular}{lcc}
\hline \multicolumn{1}{c}{ Antiserum } & Serum dilution & $\begin{array}{c}\text { Volume (ml) added to } \\
0.5 \mathrm{ml} \text { washed sediment }\end{array}$ \\
\hline RAH Tamm-Horsfall glycoprotein & $1: 20$ & 0.02 \\
SAR* & $1: 20$ & 0.02 \\
SAH fibrinogen* & $1: 30$ & 0.06 \\
SAH albumin* & $1: 20$ & 0.06 \\
SAH IgA* & $1: 20$ & 0.06 \\
SAH IgG* & $1: 40$ & 0.06 \\
SAH IgM* & $1: 20$ & 0.06 \\
SAH C* & $1: 20$ & 0.06 \\
SAH Clq & $1: 20$ & 0.06 \\
\hline
\end{tabular}

*Conjugated with fluorescein isothiocyanate.

\section{Results}

We observed diffuse fluorescence of casts with the antiserum to Tamm-Horsfall glycoprotein in the urines of all the healthy volunteers. These rarely showed a positive reaction to other antisera (table II) None contained immunoglobulins, although one gave a positiv reaction for fibrin and $\mathrm{Clq}$, one for $\mathrm{C} 3$ and $\mathrm{Clq}$, and one for only Clq.

Only one of the 60 patients with glomerulonephritis showed the pattern seen in the healthy subjects (table II)-namely, a positive reaction for Tamm-Horsfall protein alone. All 60 patients gave a positive reaction for Tamm-Horsfall protein, and in addition 40-50\% gave positive results for each of fibrin, IgA, IgG, IgM, and C3. Few of their casts contained Clq or albumin.

No clear cut pattern emerged that was characteristic of any particular type of glomerulonephritis, and the pattern did not appear to reflect glomerular deposits. Thus, although IgA was present in casts from nine $(47 \%)$ of the 19 patients with mesangial IgA nephropathy, it was also detected in casts from $23(56 \%)$ of the 41 patients with other forms of glomerulonephritis; and fibrin was not detected in urinary casts from two of the five patients with crescentic glomerulonephritis even though the urine was examined close to the time of a renal biopsy showing crescents. Similarly, IgG was detected in cast from only three of the five patients with lupus nephritis and in only seven of the 12 patients with membranous glomerulonephritis. The single patient with the minimal lesion nephrotic syndrome showed positive reaction for all immunoglobulins, fibrin, and C3. This shows that serum proteins may be present in casts from patients with selective proteinuria.

Table III shows the urine sediment and renal biopsy findings in 31 patients whose urine was examined close to the time of renal biopsy. The pattern of protein deposition within casts in renal tubules did not correspond to that in urinary casts in any patient. As casts are not always seen in tubules in biopsy specimens a negative result a biopsy may have indicated the complete absence of casts or that casts were present but did not react with particular antisera. Most of the patients showing fluorescence of casts in their biopsy tissue with any of the antisera also showed a positive reaction in their urine sediment.

Repeat studies were undertaken in seven patients (table IV). Three gave negative results for immunoglobulins and complement on the second sampling; the results for the remaining four patients were similar on both occasions. The three in whom urine findings improved had all shown substantial improvement in clinical variables after treatment-namely, resolution of the nephrotic syndrome (case 1), disappearance of crescents on biopsy (case 5), and amelioration of clinical symptoms of membranous glomerulonephritis (case 7).

The six patients with essential hypertension showed the same pattern as healthy subjects-namely, positive staining with only 
TABLE II-Protein composition of urinary casts in healthy subjects and patients classified according to their clinical or histological diagnosis

\begin{tabular}{|c|c|c|c|c|c|c|c|c|c|c|}
\hline \multirow{2}{*}{ Diagnostic group } & \multirow{2}{*}{$\begin{array}{l}\text { No in } \\
\text { group }\end{array}$} & \multicolumn{9}{|c|}{ No of positive reactions for: } \\
\hline & & $\underset{\text { protein }}{\text { Tamm-Horsfall }}$ & Albumin & Fibrin & IgA & IgG & IgM & $\begin{array}{c}\text { Total } \\
\text { immunoglobulin }\end{array}$ & $\mathrm{C}_{3}$ & $\mathrm{Clq}$ \\
\hline $\begin{array}{l}\text { Glomerulonephritis: } \\
\text { IgA nephropathy } \\
\text { Diffuse crescentic glomerulonephritis } \\
\text { Focal and segmental hyalinosis and sclerosis } \\
\text { Familial glomerulonephritis } \\
\text { Focal and segmental proliferative glomerulonephritis } \\
\text { Mesangial proliferative glomerulonephritis (non-IgA) } \\
\text { Minimal lesion nephrotic syndrome } \\
\text { Membranous glomerulonephritis } \\
\text { Lupus nephropathy } \\
\text { Mesangiocapillary glomerulonephritis } \\
\text { Diabetes } \\
\text { Essential hypertension }\end{array}$ & $\begin{array}{r}60 \\
19 \\
5 \\
7 \\
2 \\
3 \\
2 \\
1 \\
12 \\
5 \\
4 \\
7 \\
6\end{array}$ & $\begin{array}{r}60 \\
19 \\
5 \\
7 \\
2 \\
3 \\
2 \\
1 \\
12 \\
5 \\
4 \\
7 \\
6\end{array}$ & 1 & $\begin{array}{r}24 \\
7 \\
3 \\
3 \\
2 \\
\\
1 \\
5 \\
1 \\
2 \\
4\end{array}$ & $\begin{array}{r}33 \\
9 \\
3 \\
4 \\
1 \\
3 \\
1 \\
1 \\
5 \\
3 \\
3\end{array}$ & $\begin{array}{r}25 \\
5 \\
3 \\
1 \\
1 \\
1 \\
2 \\
1 \\
7 \\
3 \\
1 \\
3\end{array}$ & $\begin{array}{r}22 \\
7 \\
2 \\
1 \\
2 \\
1 \\
1 \\
6 \\
2\end{array}$ & $\begin{array}{r}54 \\
16 \\
5 \\
5 \\
2 \\
3 \\
2 \\
1 \\
12 \\
5 \\
3 \\
3\end{array}$ & $\begin{array}{r}30 \\
10 \\
2 \\
2 \\
2 \\
1 \\
1 \\
10 \\
1 \\
1 \\
2\end{array}$ & $\begin{array}{l}4 \\
2\end{array}$ \\
\hline Controls & 46 & 46 & & 1 & & & & & 1 & 3 \\
\hline
\end{tabular}

TABLE III-Incidence of detection of proteins in casts within renal tubules and in urine sediment from 31 patients with glomerulonephritis

\begin{tabular}{lcrrrrr}
\hline & Fibrin & IgA & IgG & IgM & C $_{3}$ & Clq \\
\hline Detected in: & 2 & 9 & 2 & 6 & 4 & 0 \\
Biopsy specimen alone & 9 & 9 & 7 & 6 & 12 & 1 \\
Urine alone & 3 & 7 & 5 & 4 & 2 & 1 \\
Biopsy specimen and urine & 14 & 25 & 14 & 16 & 18 & 2 \\
\hline Total & & & & &
\end{tabular}

These findings might be of benefit in several circumstances. After exercise urine from healthy subjects often contains numbers of casts. ${ }^{4}$ There is also an increase in glomerular red blood cells, and red cell casts may be present in a few instances. ${ }^{4}$ This has raised the question of whether a substantial increase in glomerular red blood cells or red cell casts indicates underlying glomerulonephritis. Examination of the urinary casts for fibrin, immunoglobulins, and $\mathrm{C}_{3}$ might help to answer this.

It has been suggested that as many as $20 \%$ of patients attend-

TABLE IV-Protein composition of urinary casts on repeat sampling in seven patients with glomerulonephritis

\begin{tabular}{|c|c|c|c|c|c|c|c|c|c|}
\hline \multirow[b]{2}{*}{ Case No } & \multirow{2}{*}{$\begin{array}{l}\text { Interval between } \\
\text { sampling } \\
\text { (weeks) }\end{array}$} & \multirow[b]{2}{*}{ Sample } & \multicolumn{7}{|c|}{ Reaction for presence of: } \\
\hline & & & Fibrin & IgA & IgG & $\operatorname{IgM}$ & $\mathrm{C}_{3}$ & $\mathrm{Clq}$ & $\begin{array}{l}\text { Tamm-Horsfall } \\
\text { glycoprotein }\end{array}$ \\
\hline 1 & 6 & $\left\{\begin{array}{l}1 \\
2\end{array}\right.$ & \pm & \pm & \pm & \pm & \pm & $\overline{-}$ & + \\
\hline & & 1 & - & + & + & + & + & $\overline{-}$ & $\begin{array}{l}+ \\
+\end{array}$ \\
\hline 2 & 40 & 2 & + & + & + & + & + & - & + \\
\hline 3 & 40 & $\begin{array}{l}1 \\
2\end{array}$ & \pm & \pm & $\bar{t}$ & \pm & - & - & $\begin{array}{l}+ \\
+\end{array}$ \\
\hline 4 & 30 & 1 & - & - & + & - & - & - & + \\
\hline & & $\tilde{1}$ & ${ }_{-}^{+}$ & + & $\stackrel{+}{-}$ & + & - & + & $\begin{array}{l}+ \\
+\end{array}$ \\
\hline 5 & 14 & 2 & - & - & - & - & - & - & + \\
\hline 6 & 6 & $\left\{\begin{array}{l}1 \\
2\end{array}\right.$ & $\begin{array}{l}+ \\
+\end{array}$ & $\begin{array}{l}+ \\
+\end{array}$ & \pm & $\bar{t}$ & $\bar{z}$ & $\bar{z}$ & $\begin{array}{l}+ \\
+\end{array}$ \\
\hline 7 & & $\{1$ & + & - & + & + & + & - & + \\
\hline 1 & 70 & $\{2$ & - & - & - & - & - & - & + \\
\hline
\end{tabular}

Tamm-Horsfall protein-as did three of the patients with diabetes and proteinuria (table IV). Most casts from both healthy subjects and patients showed diffuse fluorescence of cast matrix rather than the granular distribution described by Rutecki et al. ${ }^{3}$

\section{Discussion}

The presence of increased numbers of hyaline casts in the urine is widely considered to be an abnormal finding that invariably reflects damage to the renal parenchyma. Large numbers of casts are regularly seen, however, in the urine of healthy subjects after vigorous exercise, ${ }^{4}$ administration of diuretics such as frusemide and thiazides, ${ }^{5}$ and ingestion of acidifying agents or cation exchange resins. ${ }^{6}$ It would, therefore, assist in determining the pathological importance of cylindruria in particular patients if such casts were distinguishable from those seen in patients with renal disease.

Our results show a clear difference between the hyaline casts that appear in the urine of healthy subjects during exercise and those seen in the urine of patients with glomerulonephritis. Most patients were studied in an active phase of the disease while they were in hospital for renal biopsy. Our findings also suggest that when glomerular lesions resolve with treatment the urinary pattern may revert to that seen in healthy individuals. ing hypertension clinics may have underlying glomerulonephritis. ${ }^{7}$ Few units would undertake renal biopsy in all such patients, and the finding of immunoglobulin, fibrin, or complement in addition to Tamm-Horsfall protein in casts would help to confirm a diagnosis of glomerulonephritis.

Although the count of dysmorphic erythrocytes in the urine accurately identifies patients with glomerulonephritis, ${ }^{8-10}$ in some patients additional confirmation of glomerulonephritis using a less invasive procedure than a renal biopsy would be helpful. In some forms of glomerulonephritis, particularly membranous glomerulonephritis, counts of glomerular red blood cells may be close to the normal range. In these cases patients may not have proteinuria, but, in addition to showing a slight excess of glomerular red cells, their urine usually contains casts. Analysis of the composition of these should help to confirm the diagnosis.

Our findings differ from those of Rutecki et al, who reported granular deposits in casts and no diffuse staining of the matrix in the nephrotic syndrome. ${ }^{3}$ Although a few granules were noted in many casts, there was almost always staining of the cast matrix in addition to granules.

We had hoped that this study might show differences in the urinary casts in different forms of glomerulonephritis, but it did not. There was no apparent relation between the pattern of immunoglobulins, fibrin, and complement in glomeruli and the urinary findings. A better correlation was noted between the 
presence of immunoglobulins, fibrin, and complement in casts in the biopsy specimen and their presence in the urine. Casts are not always observed in a biopsy specimen, and hence this comparison is most meaningful in cases in which a positive result is recorded for casts in the biopsy specimen and a negative result for casts in the urine. This occurred in only one out of 31 patients.

Glomerulonephritis is a common disease and is being identified more often in asymptomatic patients as simple dipstick methods of urine analysis become more widely used. Although a renal biopsy gives the only definitive diagnosis of glomerulonephritis, careful analysis of the microscopic findings in the urine, particularly glomerular erythrocyte counts, ${ }^{910}$ will identify most cases of glomerulonephritis. Staining of casts for complement, immunoglobulins, and fibrin provides another noninvasive method of diagnosing glomerulonephritis.

We are indebted to Professor P Kincaid-Smith for the histological assessment of renal biopsy specimens, Dr J P Dowling for the immunofluorescence reports on renal biopsy specimens, and the Renal Research Institute for financial support.

\section{References}

${ }^{1}$ Addis T. The renal lesion in Bright's disease. Harvey Lect $1929 ; 23$ 222-50.

${ }^{2}$ McQueen EG. Composition of urinary casts. Lancet 1966;i:397-8.

${ }^{3}$ Rutecki GJ, Goldsmith C, Schreiner GE. Characterization of proteins in urinary casts. $N$ Engl $\mathcal{F}$ Med $1971 ; 284: 1049-52$.

${ }^{4}$ Fasset RG, Owen JE, Fairley J, Birch DF, Fairley KF. Urinary red-cell morphology during exercise. $\mathrm{Br} M e d$ f 1982;285:1455-7.

5 Imhof PR, Hushak J, Schumann G, Dukor P, Wagner J, Keller HM. Excretion of urinary casts after the administration of diuretics. $\mathrm{Br}$ Med ₹ 1972;ii:199-202.

${ }^{6}$ Friedman IS, Zuckerman S, Cohn TD. The production of urinary casts during the use of cation exchange resins. Am f Med Sci $1951 ; 221$ : 672-7.

${ }^{7}$ Mowbray JF, Kapoor A, Porteck A, Peart WS. Significance of haematuria in hypertensive patients. Lancet $1980 ; \mathrm{i}: 231-2$.

${ }^{8}$ Birch DF, Fairley KF. Haematuria: glomerular or non-glomerular? Lancet 1979 ;ii :845-6.

${ }^{9}$ Fairley KF, Birch DF. Hematuria: a simple method for identifying glomerular bleeding. Kidney Int 1982;21:105-8.

10 Birch DF, Fairley KF, Whitworth JA, et al. Urinary erythrocyte morphology in the diagnosis of glomerular haematuria. Clin Nephrol 1983; $20: 78-84$.

(Accepted 3 October 1983)

\title{
Change in risk factors for coronary heart disease during 10 years of a community intervention programme (North Karelia project)
}

\author{
PEKKA PUSKA, JUKKA T SALONEN, AULIKKI NISSINEN, JAAKKO TUOMILEHTO, \\ ERKKI VARTIAINEN, HEIKKI KORHONEN, ANTTI TANSKANEN, PÄIVI RÖNNQVIST, \\ KAJ KOSKELA, JUSSI HUTTUNEN
}

\begin{abstract}
A comprehensive community based programme to control cardiovascular diseases was started in North Karelia, Finland, in 1972. Reductions in smoking, serum cholesterol concentrations, and blood pressure were among the central intermediate objectives. The effect of the programme during the 10 year period $1972-82$ was evaluated by examining independent random population samples at the outset (1972) and five (1977) and $10(1982)$
\end{abstract}

\footnotetext{
National Public Health Institute, Department of Epidemiology, Mannerheimintie 166, 00280 Helsinki 28, Finland

PEKKA PUSKA, MD, MPOLSC, professor, director of the North Karelia project, director of department of epidemiology

AULIKKI NISSINEN, MD, NT, senior researcher, co-principal investigator of North Karelia project

ERKKI VARTIAINEN, MD, senior researcher

HEIKKI KORHONEN, MD, researcher

PÄIVI RÖNNQVIST, MPOLSC, researcher

JUSSI HUTTUNEN, MD, director, professor

University of Kuopio, Research Institute of Public Health, Box 138, 70101 Kuopio 10, Finland

JUKKA T SALONEN, MD, professor, co-principal investigator of North Karelia project

JAAKKO TUOMILEHTO, MD, MPOLSC, consultant, co-principal investigator of North Karelia project

ANTTI TANSKANEN, MD, acting professor

National Board of Health, Office of Health Education, Box 224, 00531 Helsinki 53

KAJ KOSKELA, MD, MPOLSC, chief of office of health education

Correspondence to: Professor Pekka Puska.
}

years later both in the programme and in a matched reference area. Over 10000 subjects were studied in 1972 and 1977 (participation rate about 90\%) and roughly 8000 subjects in 1982 (participation rate about $80 \%$ ).

Analyses were conducted of the estimated effect of the programme on the risk factor population means by comparing the baseline and five year and 10 year follow up results in the age range 30-59 years. The effect of the programme (net reduction in North Karelia) at 10 years among the middle aged male population was estimated to be a $28 \%$ reduction in smoking $(p<0.001)$, a $3 \%$ reduction in mean serum cholesterol concentration ( $p<0.001)$, a $3 \%$ fall in mean systolic blood pressure $(p<0.001)$, and a $1 \%$ fall in mean diastolic blood pressure $(p<0.05)$. Among the female population the reductions were respectively, $14 \%$ (NS), $1 \%$ (NS), $5 \%$ (p $<0.001$ ), and $2 \%(p<0.05)$.

During the first five years of the project (1972-7) the programme effectively reduced the population mean values of the major coronary risk factors. At 10 years the effects had persisted for serum cholesterol concentrations and blood pressure and were increased for smoking.

\section{Introduction}

After the second world war cardiovascular diseases, predominantly coronary heart disease, became the leading public health problem in most of the industrialised world. Mortality statistics and other studies showed that in the 1960s the highest heart disease mortality rates were observed in Finland, predominantly in men. ${ }^{1-3}$ Within Finland the highest rates were registered in eastern Finland and were particularly high in the county of North Karelia. ${ }^{45}$ A major national project was there- 